\title{
EFFORTS OF INCLUSIVE PRACTICES FOR PARENTS IN CHILDREN DAY CARE CENTERS: WHEN CHILD FAILS TO ATTEND SCHOOL
}

\author{
Julija Eidukevičiūtė, Nijolė Petronèlė Večkienė \\ Vytauto Didžiojo universitetas
}

\begin{abstract}
In this article the efforts of social workers to promote inclusive practices in children day care centres is analysed. Changes in education based on life-long learning culture require active and conscious participation of parents in child's education process. However, this participation becomes overburden if family is socially excluded because of the deviant lifestyle or poverty. Indeed, practical observations together with results of the studies reveal that the collaboration between social professions, which aim to implement child welfare and parents is insufficient. In order to help these families children day care centres were established. The aim of the article is to reveal how social workers construct professional help with parents on the purpose to help overcoming child's issues at school. The study is based on hermeneutical methodology. During Soviet period development of child's skills belonged to the educational institutions outside the family. Research participants still struggles for the ownership of these developments, pushing neglectful parents aside. The research revealed that within transformation process social workers adapts the forms of professional posture, however, the content of their performance is inherited from the past experiences and historical development. KEY WORDS: childhood, empowerment, social work, parents, education.
\end{abstract}

\begin{abstract}
Anotacija
Šiame straipsnyje analizuojamos socialinių darbuotojų, dirbančių vaikų dienos centruose, pastangos plètoti vaiko mokymąsi ịgalinančią praktiką kartu su šeima. Šiuolaikinė mokymosi visą gyvenimą paradigma skatina aktyvų, sąmoningą tėvų dalyvavimą vaikų mokymosi procese. Jis apsunkinamas, jei šeima išgyvena socialinę atskirtị dẻl skurdo, visuomenèje nepriimtino gyvenimo būdo. Praktinių situacijų stebejjimas ir tyrimų rezultatai atskleidè, kad siekiant padèti atskirtị išgyvenančiai šeimai būtinas socialinių profesijų atstovų, iggvendinančių vaiko gerovès programas, ir šeimos bendradarbiavimas, kurio vis dar stinga. Straipsnyje siekiama atskleisti, kaip socialiniai darbuotojai konstruoja pagalbą tèvams, siekdami kartu su jais padèti vaikui ịveikti mokykloje patiriamus sunkumus. Pristatomi kokybinio hermeneutinio tyrimo rezultatai. Tyrimas atskleidè, kad transformacijų procese socialiniai darbuotojai keičia savo profesinę laikyseną. Tačiau jų teikiamos pagalbos šeimai turinys, perimtas iš praeities ir nulemtas istorinio konteksto, išlieka nepakitęs. Tyrimo dalyviams - socialiniams darbuotojams - sunku dalintis atsakomybe su vaiku nesirūpinančiais tèvais, nes praeityje, tarybiniu laikotarpiu, vaikai ugdyti švietimo institucijose, t. y. už šeimos ribų.

PAGRINDINIAI ŽODŽIAI: vaikystė, įgalinimas, socialinis darbas, tèvai, švietimas.
\end{abstract}

DOI: http://dx.doi.org/10.15181/tbb.v76i1.1510

\section{Introduction}

The 25 years of social transformations in independent Lithuania allowed social professions to accumulate experience based on local understanding of the social 
issues. This experience allows having common sense between professionals providing services for child and family. The appearance of common sense between actors of the interaction in the area of child protection requires time length to uncover common understanding. Gadamer (1984) insists that understanding is essentially a historically effected event.

Changes in education based on life-long learning culture require active and conscious participation of parents in child's education process. However, this participation becomes overburden if family is socially excluded because of the deviant lifestyle or poverty. Indeed, practical observations together with results of the studies reveal that the collaboration between social professions, which aim to implement child welfare, and the parents is insufficient. In order to help these families there children day care centres were established. This nongovernmental setting is understood as agencies, providing social services for excluded families and their children, also services of preschool and additional education. In this context social workers become the mediators between family and the outside formal social life, in the case of this article - school system.

The aim of the article is to reveal how social workers construct professional help with parents on the purpose to help to overcome child's issues at school. In order to disclose this aim the following objectives were formulated: 1) to disclose the development of children day care centres in Lithuania; 2) to discuss habitus of school and parents interaction in relation to the childhood; 3) to explore reproduced social relations in family social work practice: when child fails in school attendance.

This article is reflects the results of Eidukevičiūte (2013) study, which is based on hermeneutical methodology (Gadamer 1984). According to hermeneutical methodology researching everyday practices allows recognising the habitus projected from the past horizon, and understanding of the social worker from the present which evolves into the future family social work.

Eidukevičiūtè (2013) in her study revealed obstacles for social workers to promote inclusive practices for the adult family members. With the purpose to overcome these obstacles the professional reflection and awareness of horizons between present and past becomes crucial.

\section{The development of children day care centres in Lithuania}

As mentioned previously, the children day care centre is described as agency, providing social services for excluded families and their children. In day care centres children are fed, educated, centres provide facilities to play, prepare festivals, and participate in cultural, ecological and other events. In order to encourage 
parents to take better care and education of their children, the day care centres organize social work with the families. Here the parents may get psychological and pedagogical help depending on possibilities. The purpose of such help is to eliminate causes which are named as reasons for children to loose parental care. Social work with socially excluded families aim to strengthen families and helps to become more functional.

However the setting which evolves from the Ministry of Education in 1996 at the beginning was not so much intended to link the childhood to the education system. The children day care centres initiated activities facilities in order to deal with children delinquency, involvement into vagrancy and beggary and create prevention for the issues. The relation with the education system evolved under leadership of the Ministry of Social Security and Labour after 2002. Then National children day care centres were set and all responsibilities for the development of their facilities were taken by the Ministry of Social security and labour. National program of children day care centres emphasized the importance of fulfilment of basic children's physical needs, and the prevention of dropout from the education system. Services for parents in this setting still are considered as supplementary services, all attention is focused on child.

In order to discuss parent's role in relation to the child's education we analysed many social profession researches conducted in Lithuania. We concluded that much of the practices implemented by the research participants would depend on the research participants' attitude towards their own roles and the perceptions of a child and parental figure.

When reading research reports on issues of school attendance, it seems that this theme is part of the childhood discourse (Kvedaravičiūte 2007, p. 131). There are no discussions on long lasting consequences of school nonattendance in Lithuania. School attendance is related to obligatory or natural part of the childhood. However, issues at school are considered as the sign for possible disadvantage in the child's future (Barkauskaite Žadeikaite 2006, p. 39). Education of children is related to the possibilities of choice in the future. Research by Barkauskaite, Radzevičiūte (2004, p. 93) has shown that educators tend to relate school issues with family status. According to the research, the lack of parent's interest to child's education conditions leads to the lack of child's learning motivation. Research by Indrašienè, Suboč $(2008$, p. 115) conducted several years later broadens the understanding of a child's difficulties at school, and discussion of school issues also becomes related to school environment.

If children day care centre is considered as the setting reproducing traditions inherited from extended-day groups which were situated at school, then the research participants should replicate habit and rules originating from the sustaining setting. 
Tradition, according to which the setting evolves, has educational background. The tradition of habitus originated in the period of the Soviet Union. That was the basis for replication of certain relationships between children and educators. It can be assumed that parents can be outsiders to the educational system, as it was mainly dedicated to formation of children as future communist society.

\section{Habitus of school and parents interaction in relation to the childhood}

The habitus according to Bourdieu (1990, p. 54) is a product of history, which produces individual and collective practices in accordance with the schemes generated by history. It ensures the active presence of past experiences, which, deposited in each organism in the form of schemes of perception. Through the action habitus tend to guarantee the "correctness" of practices and their constancy over time, more reliability than all formal rules and explicit norms. To identify unwritten rules, which sustains the existing social forms, Zdravomyslova, Voronkov (2002, p. 61) suggest to analyze through the tacit practical knowledge, which is not articulated if the experience of living does not make it problematic. Individuals follow daily, as if automatically, the routine, not paying attention to what they actually do, or how and why. By everyday life, it is meant routine social practices that differ along social networks or social milieu. According to the researchers, thus issue for social science is that the empirical evidence of late Soviet everyday life has not yet been collected and lacks of conceptualization. There is still an insufficient conceptualization of everyday morality as a form of implicit knowledge as well as of the concrete social practices of everyday coping.

During the Soviet period childhood had special meaning in social policy. Childhood was perceived as a special period of a person's development, passive, in need for shaping and control by adults. Childhood had to be constructed, and controlled as Svadovkij (1970, p. 348) notes that lack of care and adequate organization of the day often produced children's hooliganism and misbehaviour. Therefore big emphasis was put on the role of education. If a child was left alone after school, he/she was considered to be at risk of school failures and malnutrition. One way to solve the issue was to keep children at school for some time after lessons under supervision and guidance of the teachers. Subbostkii (1992, p. 94) referred to children's pragmatic (rule or consequence guided) moral conduct that depended heavily on external controls. According to the author, for the child's development it was important to examine influential sources for external control: peers and adults.

In the Soviet education, much attention was paid to the attitude towards labour, which should be obvious for the Soviet man, closely connected and fostered in 
the collective. Love for the labour, according to the Tudge (1991, p. 131), was supposed to determine in children very early, certainly during preschool years, to be fostered in kindergarten and not directly at home. The main difference is age at which children are first encouraged into these types of activities, and the fact that the goal is not primarily to assist parents (or more accurately in the Soviet context, the mother) but to introduce attitude of the value of labour.

On one hand, the requirement to take care of child's education resulted from national programs of day care centres. The focus on child, in particular during primary school, also evolved from previous establishments. During the Soviet period, there were prolonged groups for children in every school. These groups were active mostly in primary schools, to support working parents. Groups providing services to children had the same aims as children day care centres - afterschool occupation, provision of nutrition, and accomplishment of homework. These were the task for parents, in particular mothers, but supplemented by those establishments.

Doubt that arose during the research process - the central figure considered as being responsible for control of child's school performance - the mother. Family as a unit is divided into different parental figures depending on gender, where mothers are responsible for afterschool education, as this establishment was dedicated to increase mother's and women's employment. Svadovskij (1970, p. 342), who discussed the importance of interaction between family and educators, prioritized the needs of the state that had developed the system helping women to participate in labour market. Moreover, emphasis was put on equal rights between men and women; therefore, women was not supposed to be overburdened with her work in the family and at home and be confined to the small family cell only. The policy of the Soviet state and social organizations was to liberate family from everyday work at home and give parents time and conditions to bring up children in proper way. It should be taken into account that upbringing of the future Communist society was the main goal given for a family. Education of children and provided facilities were established not to provide support for a family as a social unit, these establishments were rather focused exclusively on the role of mother.

This liberation of mothers from daily chores could also be explained by distancing of the parents, mothers, from decision making in the process of child education. Practices of research participants did not involve parents into solving family situations. As mother is considered neglectful, her role as a representative of the child's interest is replaced by a professional working outside the education system. Another factor triggering provision of social services for the mother is that in this situation the mother becomes a mediator between child and education system. However, mother's responsibility is not to monitor the process of education, 
but to help educators educate the child. In the case of failure, she is blamed for the irresponsible and neglectful behaviour towards the child.

Indeed, education as a system implementing family social policy, in the case of conflict with values, had the power to decide on behalf of child's interests. As it has already been mentioned, the entire education system was highly politicized. Thus, differences between societal and family values were considered as having political conflict. Geiger (1956, p. 188) observed that the totalitarian system of the Soviet Union in the orientation of youth clashes with the traditionally sanctioned attitudes of parents. Researcher also pointed out that the problem areas in the parent-child relationship applied not only to matters considered 'political' or focused to accept socially agreed values. This area had traditionally been central importance to parent-child relationship. Social workers could face the issue of reproducing relation with parents as possibly deviant for youth orientation, and placing themselves into opposition of the parents as moral agents, and challenge parent's worldview towards their children. Educators were taking over the role of parents, replacing the needs of parents with the party strategies. In this understanding, mothers educating children with different understanding were perceived as triggers and interference into child's educational achievements.

Khliovskaya Rockhill (2010, p. 54) analyzing the Soviet legislation legitimating consequences for parents in case of child neglect has noted that in the year 1936, together with freedom of marriage, abortion and divorce, parental duty was proclaimed as sacred. Moreover, maternity was treated as the most important function of women, as a state's function, in which case participation in the labour force mandatory, became a subordinate priority. Paternity was no longer treated as biological fact, but rather as a legal obligation deriving only from registered marriage. Legislation introduced parental responsibility and criminal penalties for neglectful parents and guardians. The problem of unsupervised children was seen as rooted not in poverty but in poor work of the Soviets, the Party, and the Komsomol.

The Ministry of Education of the Soviet Union was required to advise social organizations, such as trade unions and parents' places of work, to fill in the gap of the absence of parental supervision and of parents' failure to 'correct' their ways, to initiate proceedings for terminating their parental rights. It was claimed that crime by the state, child neglect was no longer motivated by social condition. Officials sought to make parents responsible for their children's behaviour by establishing repressive measures to enforce parents' responsibility.

Another aspect should be taken into account that education system in the Soviet period had the right to evaluate parenting, and make decisions over replacement child from the family. In the Soviet times detection of family issues and procedure for child's replacement began at school. School, not parents, was obligated to care 
about education of children and teenagers. Information about pupils who were not attending school or were delinquent was collected and was in concern of special rooms in the militia. Thus, education system was responsible for the issues of childhood.

\section{Reproduced social relations in family social work practice: when child fails in school attendance}

According to Howe (2002), the social workers in their day-to-day practice face a busy and complex person's world in certain social context. Thus, social workers try to understand and make sense of people and the situations in which they try to act professionally. If social workers try to cope with and be competent in social situations, he/she develops more deliberate, systematic and formalized situation. Social work as an activity is shaped by institutional context. What social workers do - the practices they adopt, the values they act upon, the outcomes they pursue - are very much the result of the gradual accumulation of past practices and understandings within profession which gradually taken on a more or less 'accepted' status. Layder's (1998, p. 91) presents idea that settings are in large part made up of reproduced social relations. It means that people generally replicate the habits, traditions and rules that sustain their social forms.

Social workers participated in the study emphasize the importance of afterschool activities. At first it seemed understandable per se: creating an alternative and controlling space for the street relationships and culture for the children. On the other hand, research participants providing supplementary role involving services in relation to school and education activities. Child protection professionals associate child's performance at school with the neglectful behaviour of the parents.

Research participants' concern over the entire helping process aimed at keeping the child in education system seems contrasting at the first glance. Investment into the child's future also determines the possibilities to have choices during the adulthood. It could be discussed that research participants do not ask how to overcome family poverty and exclusion, but rather concentrate on preventing drop-out from school.

Social worker Leonas [3.1.83] tells about a case of a boy's school nonattendance. The boy should come to day care centre after school, but the research participant noted, that the boy has been coming to day care centre at the time when the lessons at the school ends, but he was not going to school and mainly he spent the day at the streets. Issues related to attendance of school are perceived by the research participant as violation of norms for a child. The issue of nonattendance is related by Leonas to the lack of control at home, when the mother has lost hope 
of being able to have control over the boy's behaviour. As a result, social worker takes over the situation informing the mother about the issue.

[exactly yes. you know so *instead of fighting there with that child in the morning, and ((if)) trying to wake him up to school or no, what happens is that parents also oversleep first lessons, of course ((they)) do not wake the child up, that is so fairy tricky for him to wake up by himself if nobody encourages him.* so he is fine otherwise there, some sort of matters in the town and mother there you are takes child, that so:o he would help with the matters or something like this. and so again child does not attend, if not ((does not attend)) all lessons, then suppose part of the lessons.. $=3.1 .96$.

Leonas discusses the helping process abstractly, focusing on the reasons that condition the nonattendance of the children. He emphasizes the importance of control in a child's relation to school. However, Leonas tells about case being confident that he has not informed the mother about the issues the child faces. Instead, the research participant starts describing the importance of relationship with the child in solving the lack of learning motivation. Involvement of parents in the solution of the issue is not mentioned by research participant.

When describing the situation, Leonas avoids the relationship with parents, devalues their ability to change the situation. His arguments for this position are that the mother has lost hope to control the boy's behaviour and she is not taking issues responsibly. Instead of the indifferent mother, the research participant places himself into relationship with child as a caring and strict person, performing the supervisory role allegedly more successfully than the mother. Also, during the interview Leonas talks in outraged voice describing the time the child spends with mother while he should be at school. Lack of discipline and control over school attendance according to Leonas is the sign of the mother's neglectful behaviour. The inability to control school performance prompts the research participant to perform the role of mother in the children day care centre.

In the extract [1.1.32], social worker Joana relates possibility for family to become service recipient of children day care centre mainly with the child's belonging to the education system. Child's age and membership in a day care centre is measured by belonging to the education system, thus involvement into school. Even when describing the child's age, Joana names the grade the child is going to at school. Parents are responsible for supply, social worker in day care centre for the content of the relationships formed by child. Indeed, parents are bridging the relationship with the outside world, this is the domain of their power. Parents also become responsible for the child's behaviour outside. In the case the child breaks the behavioural norms, it is considered to be the parents' fault. 
In case a child is a teenager, the research participant distances herself from personal involvement with the child. She intervenes into the role of the mother, which, according to her understanding, has obvious signs of the lack of control over the child's behaviour. According to Joana, in the case of travelling mother [1.1.38], neglectful mother should be replaced by foster care. Social worker is not looking for relationship with child, just taking care of the possibilities to replace the supplier, i.e. the mother.

In extract [5.1.240] social worker Edita presents her attitude towards child's ability to fit into educational system. While discussing the child's good achievements she nonetheless emphasizes the child's unacceptable behaviour at school. She links the boy's issues at school with the same observed behaviour at the children's day care centre, which she named as a feature of the a mental disease. The issue for the research participant is the mother's unwillingness to seek prescription and treatment by doctors, as the boy's diagnosis would allow the professionals to apply specific treatment. Resistance to rules of the setting is perceived as the issue of mental health. However, there is contradiction in Edita's understanding of the issue and the ways of dealing with it. At the beginning of the extract, she points out that the boy has good achievements at school as a pupil, but the issue for the professionals is that the child demands good behaviour towards him during the interaction. At the end of the same extract, Edita implements the facilitated program, which is used for children with special issues. It is important to notice that adaptive programs are implemented at school for children who face difficulties with learning achievements. Child's inability to manage situations at school is related to mother's inconvenient lifestyle: lonely motherhood, unemployment, jobbing, and alcohol consumption. Evaluation of the child's achievement at school varies from good to poor, mental disease that should be treated manifests itself in reluctant behaviour demonstrated by angrily telling orders and requiring attention. The issue for Edita is impossibility to control the boy's behaviour and mother's avoidance to follow the instructions. Moreover, the boy's inability to follow daily routines willingly is qualified as consequence of mother's neglect.

Concentration on economical morality, which was so emphasized in the Soviet Union through the total employment, challenged the role of parent - child relation. Development of child's social and cognitive skills belonged to the institutions outside the family. Research participants still struggles for the ownership of these developments, pushing parents, and especially mothers, aside. The research revealed that within transformation process social workers adapts the forms of professional posture gained through understanding of social work, however, the content of their performance is inherited from the past experiences and historical development. 
Question is for the future researches, how this gained and transformed practice of social work with families in special setting will develop in the future?

\section{Discussion}

1. There is separation of the family as unit into children and parents. The children day care centres infrastructure which at first was established as a mean to solve children delinquency problems evolved according to the habitus. The agencies which are not part of education system, and are more participant of child protection setting, at some point begin to fulfil the education gaps with the most vulnerable members of society - children of the excluded families. The aim of the children day care centres according to the National program of children day care centres are to meet basic needs of the children, and help to stay in the education system. Social work with parents is voluntary part of the social worker's helping process, which professionals can interpret according individual attitudes and experience.

2. Education system in the Soviet period had the right to evaluate parenting, and make decisions over replacement child from the family. In the Soviet times detection of family issues and procedure for child's replacement began at school. School, not parents, was obligated to care about education of children and teenagers. Information about pupils who were not attending school or were delinquent was collected and was in concern of special rooms in the militia. Thus, education system was responsible for the issues of childhood.

3. The issue of children coming to the day care centres is an unusual issue. The responsibility of parents in relation to school is to be 'gatekeepers' and relate child with the school and assure quality of education. In the case of parent figure's unwillingness to take care about child's school performance, they are considered as neglectful. Parents' neglectful behaviour towards children is considered to be a social worker's concern. The lifestyle of the mother of poor family and the lifestyle of women working as social worker can be very different. Social worker experiences alienation towards the responsibilities which mothers have to carry out with poorly accessible resources. The huge gap of realities and prejudices of what is acceptable for parenting in the contemporary society construct the possibilities of incoherence for family social work practice. 


\section{Bibliography}

Barkauskaitè, M., Rodzevičiūtè, E. (2004). Nenoro mokytis priežastys mokinių ir mokytojų požiūriu. Pedagogika, Nr. 70, p. 89-93.

Barkauskaitė, M., Žadeikaitė, L. (2006). Santykiai kaip žmogaus ugdymo metodologinė paradigma. Pedagogika, Nr. 83, p. 39-44.

Bourdieu, P. (1990). The Logic of practice. Stanford University Press.

Eidukevičiùte, J. (2013). Family Social Work Practices in the Context of Transitional Lithuanian Society. Acta Universitatis Lapponiensis, Vol. 250. Lapin yliopistokustannus: Rovaniemi.

Field, G. F. (1987). The contemporary Soviet family: problems, Issues, and Perspective in Soviet Society under Gorbachev. Edit: M. Friedberg, H. Isham. Current trends and the Prospects for Reform.

Gadamer, H. (1984). Truth and Method. The Crossroad Publishing company.

Indrašienè, V., Suboč, V. (2008). Sociopedagoginès pagalbos vaikams, patyrusiems mokymosi nesekmes, prielaidos. Pedagogika, Nr. 89, p. 115-122.

Kvederavičiūtè, I. (2007). Nevyriausybinių organizacijų vaidmuo sprendžiant socialines „gatvès vaikų“ problemas. Pedagogika, Nr. 88, p. 131-137.

Layder, D. (1996). New strategies in Social Research. Cambridge: Polity Press.

Subbotski, E. V. (1992). Moral Socialization of the Child in the Soviet Union from the Birth to the Age Seven in Parent. Ed. L. Jaipaul Roopnarine, D. Bruce. Child Socialization in Diverse Cultures. Carter, Greenwood Publishing Group.

Svadkovskij, I. F. (1970). Family and School. International Review of Education, Vol. 16 (3), p. 341-350.

Tudge, J. (1991). Education of Young Children in the Soviet Union: Current Practice in Historical Perspective. The Elementary School Journal, Vol. 92 (1), p. 121-133.

Zajda, J. (1988). The Moral Curriculum in the Soviet School. Comparative Education, Vol. 24 (3), p. 389-404.

Zdravomyslova, E., Voronkov, V. (2002). The Informal Public in Soviet Society: Double Morality at Work. Social Research, Vol. 69 (1), p. 49-69. 
